establishment of the Buffalo Park herd the numbers have increased rapidly: in all, 6,673 have been shipped alive to be established in the northern Wood Buffalo Park in the North West Territories ; including those of 1932 , a total of 8,680 have been slain, and the meat, hides and heads disposed of ; and there remain in Buffalo Park 6,300 individuals. So that the minimum total of individuals bred there from the original 631 is 21,653 ; but many must have died a natural death (and there are persistent rumours of tuberculosis in the herd) and there may have been an increase also in Wood Buffalo Park. The experiment of transferring one race of bison, the plains variety, to the sole territory of another and dwindling race, the wood bison, was viewed with much concern by naturalists when it began in 1925, and it would be reassuring if the Department of the Interior of Canada would issue some information, not only about the welfare of the transferred animals (which they have done), but about the welfare of the wood bison the territory of which was invaded, and about the chances or reality of cross-breeding between the two forms.

\section{Men of the Trees}

WHILST a forest officer in East Africa, Mr. St. Barbe Baker formed a small society, which he named the 'Men of the Trees', to encourage the tribesmen to curtail the thoughtless, wasteful destruction of the forests which is still so common a feature in many parts of the world. On his return home, Mr. Baker started the Association bearing this name (The Men of the Trees) in Great Britain, the Association now being in its ninth year. The broad aim of the Men of the Trees, as exemplified by the motto, is "To develop a tree sense in every citizen and to encourage all to plant, protect and love trees everywhere", is applicable to many parts of the British Empire. The Society's object is even wider for it "not only encourages the protection, preservation and beautifying of the countryside, since no village or landscape can be complete without its trees-but its range is both national, imperial and international. It appeals equally to all creeds and to all classes". Enthusiasm for the tree in its many varying degrees of importance is the main note and its claims to form a point of union for all those to whom trees and the life of trees have an instinctive appeal. Probably, one of its most valuable activities, so far as the future is concerned, is the endeavour to interest the young people, guides, scouts and school children generally, in tree-planting and the protection of planted trees. The address of the Secretary of the Association is 32 Warwick Road, London, S.W.1.

\section{Lost Birds of Madagascar}

Is addition to two short articles dealing with the preservation of wild life in Sierra Leone and Gambia, and a summary of the very important report of the Malaya Commission, the current number of the Journal of the Society for the Preservation of the Fauna of the Empire contains a discussion concerning two little-known extinct birds of Madagascar. The 'poulet rouge', a flightless bird with a kiwi-like appearance, and the 'corbeau indien', a stout-bodied, parrot-like bird with a crest upon its forehead, are unknown except for some odd bones and a few contemporary drawings. Dr. Graham Renshaw has collected the meagre information which exists about these curious birds, one apparently a ground bird, the other arboreal, and has illustrated his description by representations of the birds as they appear to have existed.

\section{Development of the Lightning Discharge}

Referring to the letter in Nature of September 9, p. 407, by Schonland and Collens on the development of the lightning discharge, Mr. S. E. Ashmore, 22, Soho Road, Birmingham, 21, writes to suggest that the noise heard in a wireless receiver during a storm affords confirmatory evidence. The first 'click', heard a fraction of a second before the actual flash is seen (Meteorol Mag., 68, 114, 139; 1933), may be due to the preliminary downward avalanche of electrons. 'The lightning flash 'heard' afterwards is that which Schonland and Collens describe as progressing by thermal ionisation.

\section{Announcements}

Dr. Herbert E. Ives, of the Bell Telephone Laboratories, New York, will deliver the Thomas Young oration before the Physical Society at the Royal Institution, 21, Albemarle Street, London, W.1, on October 6. Dr. Ives's subject will be "Thomas Young and the Simplification of the Artist's Palette".

Messrs. Bernard QUARITCH, Ltd., 11 Grafton Street, New Bond Street, W.1, have issued a new catalogue (No. 475) containing a selection of books on zoology and geology. The catalogue contains 1,966 items, the largest section being that of entomology, which contains some important works from the libraries of Ernest and Léon Candèze.

Applicatrons are invited for the following appointments, on or before the dates mentioned :-A temporary assistant lecturer in mathematics at the University of Leeds-The Registrar (Sept. 27). A horticultural adviser in Jersey-The Greffier of the States, States' Greffe Office, Royal Square, St. Helier, Jersey (Sept. 30). A librarian for the Pharmaceutical Society of Great Britain, 17, Bloomsbury Square, London, W.C.1-The Secretary (Oct. 3). A technical assistant for the Southend Educa. tion Committee-The Director of Education, Education Office, 20, Warrior Square, Southend-on-Sea (Oct. 4). An advisory officer on farm economics for the Department of Agriculture for Scotland-. The Establishment Officer, Department of Agriculture for Scotland, York Buildings, Edinburgh, 2 (Oct. 12). A professor of anthropology at the University of Sydney-The Registrar (Dec. 2.- Further particulars from the Universities Bureau of the British Empire, 88a, Gower Street, London, W.C.1).

ERratum.--Prof. Hans Schinz, of Zurich, informs us that Dr. Otto Stapf died at 6.30 a.m. on August 4 and not on August 3, as stated in NATurE of August 26. 